
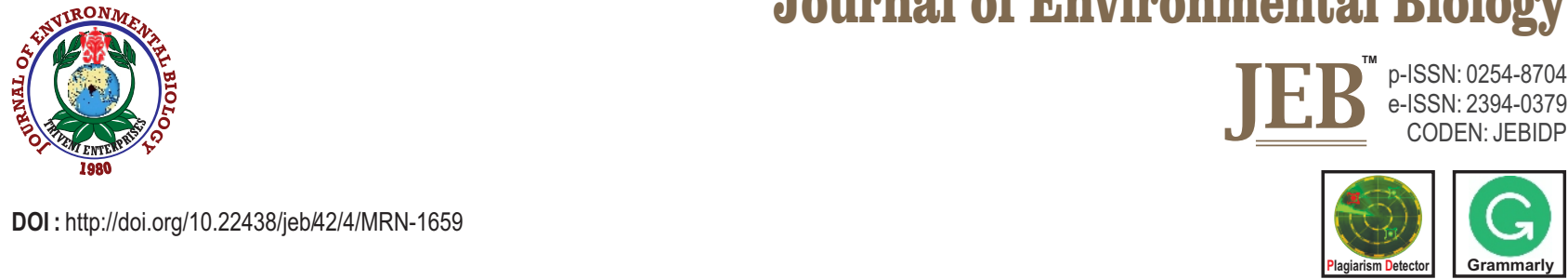

\title{
Morphometry, length-weight relationship and relative condition factor of red-toothed trigger fish, Odonus niger
}

\author{
N.K. Suyani', R. Mridula ${ }^{1 *}$, K.M. Rajesh', M.M. Meshram ${ }^{1}$ and K. Vandana ${ }^{3}$ \\ ${ }^{1}$ Department of Fisheries Resources and Management, College of Fisheries, Mangaluru - 575 002, India \\ ${ }^{2}$ ICAR-Central Marine Fisheries Research Institute, Mangalore Research Centre, Mangaluru - 575 001, India \\ ${ }^{3}$ Department of Fisheries Economics, Statistics and Extension, College of Fisheries, Mangaluru - 575 002, India \\ *Corresponding Author Email : mridularajesh789@yahoo.co.in
}

\section{Abstract}

Aim: The study aimed to investigate the morphometric and meristic measurements, length-weight relationship and relative condition factor of Odonus niger landed along coastal Karnataka.

\begin{abstract}
Methodology: The morphometric and meristic measurements, length-weight relationship and relative condition factor $\left(K_{n}\right)$ of $O$. niger was studied for a period of eight months from August 2019 to March 2020. The different morphometric characters were subjected to statistical analysis. The length-weight relationship was analyzed for both the sexes (female and male) and combined data. Monthly relative condition factor was analyzed for both the sexes and for different size group.
\end{abstract}

Results: A comparison of different morphometric measurements exhibited good extent of correlation indicating good extent of interdependence of these characters. Four out of eight morphometric characters are environmentally controlled and suggested wide range of zoogeographical distribution of 0 . niger. The lengthweight relationship is indicated as $\mathrm{W}=0.046 \mathrm{~L}^{2.565}, \mathrm{~W}=$ $0.044 \mathrm{~L}^{2.589}$ and $\mathrm{W}=0.047 \mathrm{~L}^{2.561}$ with coefficient of determination $\left(r^{2}\right)$ of $0.910,0.913$ and 0.910 for male, female and combined sexes, respectively. The ' $b$ ' values of both the sexes (male and female) exhibited negative allometric growth $(p<0.05)$ and appeared to be leaner. There was no significant $(p<0.05)$ variation for relative condition factor $\left(K_{n}\right)$ among the months and size groups. However, little higher values were observed during November and February.

Interpretation: The study fills the knowledge gap and support for developing a suitable management system for this fish species.

Key words: Condition factor, Meristic characters, Morphometry, Red-toothed triggerfish

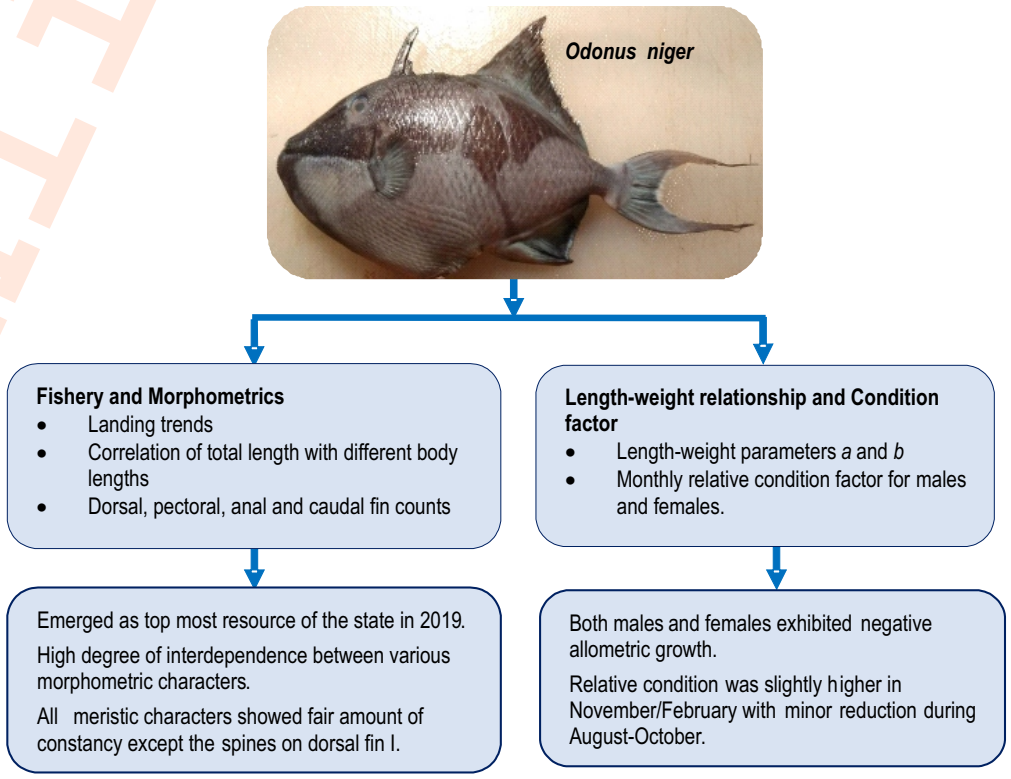

How to cite : Suyani, N.K., R. Mridula, K.M. Rajesh, M.M. Meshram and K. Vandana: Morphometry, length-weight relationship and relative condition factor of red-toothed trigger fish, Odonus niger. J. Environ. Biol., 42, 1026-1032 (2021). 


\section{Introduction}

The mainstay for taxonomic classification of organisms is to equalize the anatomical features, which modify the stock plus interrelated species, determined by using differences in morphometric and meristic traits (Bookstein, 1991). The morphological traits of fishes are the primary and foremost source of information for taxonomic and evolutionary studies. The study of morphometric characters serves as a powerful tool for characterizing strains of similar species, which involves detection of a subtle variation in the shape, independent of size. The relationship between various morphometric characters of fish can be used to determine the probable difference between unit stocks and health status of individuals (King, 1995). The length-weight relationships (LWRs) of fishes help in the estimation of average weight of fish of a given length group by establishing a mathematical relationship between the two and hence, it is considered as an important fishery management tool (Beyer, 1987; Froese, 2006). Studies on length-weight relationships are also important in fisheries because it helps to understand fish population dynamics and the growth pattern on fish stocks (Froese, 2006). Similarly, relative condition factor $\left(K_{n}\right)$ measures deviation of an organism from average weight, which indicates the growth and well being of fish (Jisr et al., 2018).

Red-toothed trigger fish (Ruppell, 1836) (Teleostomi/ Actinopterygii/ Tetraodontiformes/Balistidae) is a reef-associated species widely distributed in the tropical region of Indo-Pacific and is the only member of genus "Odonus" (Matsuura, 2014). This fish was landed in stray quantities of 300-500 t during 2008-09 along the coast of Karnataka, but did not form regular fishery until 2015. Later, the catch substantially increased to $1,62,398$ tons during 2019 to emerge as a top resource in the state $(32.3 \%$ of total fish landings) and contributed to $7.7 \%$ (2.74 lakh tons) of the total Indian marine fish landings during 2019 (CMFRI, 2020). The reasons for the abrupt emergence of this species in Karnataka coast is unknown, and studies should be initiated to investigate the possible impact on other commercial fisheries resources such as oil sardine and mackerel, which formed the major landings of Karnataka upto 2018. The entire catch of Odonus niger was utilized for fishmeal production until 2017. Later, the surumi plants procured part of it landed in fresh condition for the preparation of surumi, which is exported for the production of analogue products. The increased demand of fishmeal and surumi plants have encouraged the fishers engaged in multi-day trawl boats to target this fish.

The only study conducted on population parameters of $O$. niger along eastern Arabian Sea was by Ramachandran and Philip (2010). However, a few studies on LWRs of O. niger was conducted in Bay of Bengal Sea along the southeast coast of India (Balasubramanian et al., 1995; Sahayak, 2005; Vaitheeswaran and Venkataramani, 2008). There are no reports available on the morphometric and meristic traits, and relative condition factor of redtoothed triggerfish and hence, this study was undertaken along the Karnataka coast, India.

\section{Materials and Methods}

Samples of 0 . niger were procured on a fortnightly basis from commercial high-speed demersal trawlers at Mangaluru and Malpe Fishing Harbours of Karnataka between August 2019 and March 2020. The collected specimens were iced, packed in an insulated icebox and transported to the laboratory of Department of Fisheries Resources and Management, College of Fisheries, Mangaluru for further analysis. The overall length $(\mathrm{cm})$ and weight (g) of each individual was measured.

Various morphometric measurements were recorded by using fish measuring board and Vernier Calipers following the standard procedures (Laevastu, 1965; Dwivedi and Menezes, 1974). The morphometric characters measured were total length $(T L)$, standard length (SL), pre-dorsal fin length I (PDL1), predorsal fin length II (PDL2), pre-anal fin length (PAL), head length $(\mathrm{HL})$, snout length (SnL), eye diameter (ED) and body depth (BD). The meristic counts such as the number of spines in the dorsal fin and ventral fin, number of rays in dorsal fin, pectoral fin, anal fin, and caudal fin as well as the number of gill rakers were counted. All the ensuing measurements, calculated in percentage of total length, were subjected to statistical analysis for mean, standard deviation and coefficient of variation. Various morphometric characters were then categorized into genetically $(<10 \%)$, intermediate (10-15\%) and environmentally (>15\%) controlled characters based on their range (Johal et al., 1994). All the morphometric measurements were taken from the left side of the body of the fish and expressed in percentage of the total length. The total length was considered as independent variable, and other characters as dependent variables. A scatter diagram of various morphometry was plotted, and then, the linear regression equation was fitted using least square method (Laevastu, 1965; Snedecor and Cochran, 1967). Relationships were delineated by the equation: $Y=a+b X$, where, $Y$ and $X$ are dependent and independent variables respectively, $a$ is the constant (intercept) and $b$ is the regression coefficient (slope). The correlation coefficient $(r)$ was estimated to perceive the extent of linear relationship between two variables. The range, mean, standard deviation, and coefficient of variation estimated for meristic counts were subjected to statistical analysis (Snedecor and Cochran, 1989).

The LWRs were determined separately for male and female by the formula of Le Cren (1951): $W=a L^{b}$. This relationship can also be given in the logarithmic form as $\log W=$ $\log a+b \log L$, where $W=$ total body weight $(g), L=$ total length (cm), $a=$ intercept, $b=$ slope (growth coefficient). By performing $a$ log-log plot of length-weight pairs, extreme outliers were removed from the regression analysis. The coefficient of determination $\left(r^{2}\right)$ was used to calculate the degree of association between total 
length and weight, and $95 \%$ confidence interval of the parameters $a$ and $b$ were estimated. One-way analysis of covariance (ANCOVA) was employed to estimate the difference in the mean log weight adjusted for covariate (log length), and to check the homogeneity (equality) of regression slopes between the sex (male and female) at $5 \%$ level of significance (Snedecor and Cochran, 1967). Student's t-test was performed for estimated $b$ values to examine the growth pattern of males, females, and the combined data against null hypothesis of isometric growth $\left(\mathrm{H}_{0}\right.$ : $b=3$ ) at $5 \%$ level of significance and 356 degrees of freedom using the statistic: ts $=(b-3) / S_{b}$, where, $S_{b}$ is the standard error of the slope (Morey et al., 2003). Linear regression was performed by plotting natural $\log (\mathrm{Ln})$ of W against natural $\log (\mathrm{Ln}) \mathrm{TL}$ to find the slope and intercept.

To analyze the health status of fish, monthly relative condition factor $\left(K_{n}\right)$ was determined individually for females and males by the formula: $K_{n}=W_{0} / W_{c}$, where, $W_{o}=$ observed weight and $W_{c}=$ calculated weight (Le Cren, 1951). The data of $K_{n}$ of males and females was analyzed for different size groups $(2 \mathrm{~cm}$ intervals) to understand the health status. Statistical analyses were conducted using MS-Excel 2013 and IBM SPSS Statistics 21.0 package.

\section{Results and Discussion}

Three hundred and fifty eight specimens of $O$. niger were analyzed for morphometric and meristic investigations. The analysis of data exhibited a maximum coefficient of variation in the snout length $(10.14 \%)$ followed by eye diameter $(9.43 \%)$ and body depth $(9.10 \%)$ with lowest coefficient of variation documented in the pre-anal length (7.46\%). In taxonomic studies, morphometric characters serve as an important tool for understanding the biology of a fish. In the current study, all the morphometric characters exhibited extremely narrow range as the recorded coefficient of variation was around $7 \%$ and $10 \%$ (Table 1). This low coefficient of variation indicated least or very low intra-population variation.

On the basis of correlation coefficient ( $r$ ) and regression coefficient $(b)$, various body measurements linked to the total length of 0 . niger were compared. The most highly correlated body parameter in connection to total length was standard length $(r=0.91)$ with $p<0.01$ level of significance, while the lowest correlated body parameter was eye diameter $(r=0.28)$. The " $r$ " value indicated that only standard length shows high correlation, whereas eye diameter showed poor correlation, and other characteristics had good and moderate correlation (Table 2). A comparison of different morphometric characters showed an excellent level of correlation whereas eye diameter and total length indicated poor extent of correlation. The poor degree of correlation recorded among total length and eye diameter is linked to slow growth (Usman et al., 2016). The high value of correlation coefficient of other parameters with total length indicated a maximum extent of interdependence of these characters. The maximum total length $(24 \mathrm{~cm})$ of 0 . niger recorded in current study was comparatively lower than the total length $(31.5 \mathrm{~cm})$ reported by Ramachandran and Philip (2010) from South-west coast of India. Various authors have reported different maximum total lengths of $30.0 \mathrm{~cm}$ from Vizhinjam coast (Sahayak et al., 2015), $25.4 \mathrm{~cm}$ from the Tuticorin coast (Vaitheeswaran and Venkataramani, 2008), and $28.2 \mathrm{~cm}$ from Kanyakumari coast (Sahayak, 2005). The maximum total length recorded for 0 . niger in the Fish Base data is $50 \mathrm{~cm}$ from African waters (Smith and Heemstra, 1986).

Of all the eight characters, three (PDL1, SL, and ED) were genetically controlled having range difference of $<10 \%$; one character (PDL2) to be an intermediate category with range difference fluctuating between 10-15\%, and four characters (SL, $\mathrm{PAL}, \mathrm{HL}$ and $\mathrm{BD}$ ) were environmentally controlled having range difference $>15 \%$ (Table 3), which show a wide range of zoogeographical distribution (Vladykov, 1934). Randall et al. (1990) reported the species as widely distributed in the IndoPacific region from southern part of Red Sea to Durban in South Africa, and east to the Marquesas and Society Islands, north to Southern Japan, and south to the Southern Great Barrier Reef in Australia and New Caledonia. The species started appearing in stray quantities during 2008-09 along Karnataka coast and later emerged as a top resource in the state (CMFRI, 2020). This might be due to the migration of fish from different geographical areas and should be studied in detail. All the morphometric characters showed negative allometric growth in relation to the total length as indicated by the value of regression coefficient $(b)$. Thus, the differential growth of $O$. niger was evident and assumed to be of taxonomic interest, besides allometry could be employed for studying intra and interspecific discrepancies. Fishes are highly susceptible to environmental fluctuations and thus, quickly acclimatize themselves with changing body measurements.

Meristic traits are extensively used in fish population studies. These characters evolve at or before metamorphosis and remain fixed all through the life cycle (Okiyama, 1989). Analyses of the meristic characters indicated that the quantity of spines on the dorsal fin I (3) remained constant for the entire specimens examined, while the counts of ventral spines ranged from 11-18. The rays on dorsal fin II ranged from 32-36, pectoral fin 10-14, anal fin $26-30$, caudal fin from 10-12, and the number of gill rakers was 30-33. Of all the meristic traits studied, the coefficient of variation of ventral fin was maximum $(14.40 \%)$, followed by pectoral fin rays $(9.77 \%)$ and caudal fin rays $(6.48 \%)$ (Table 4$)$. All the meristic traits exhibited a fair amount of constancy, except the spines on dorsal fin I. The fin formula of 0 . niger landed along Karnataka waters can be drafted as: $D_{1}: I I I, D_{2}: 32-36, P: 10-14, \mathrm{~V}$ : XI-XVIII,A: 26-30, C: 10-12.

The fin formula of this study confirms with the earlier observations of Randall et al. (1990) and Padmavathi et al. 
Table 1 : Morphometric traits of Odonus nigerlanded along Karnataka coast.

\begin{tabular}{lll}
\hline Statistical estimates & Mean $\pm S D(\mathbf{c m})$ & Coefficient of Variation $(\%)$ \\
\hline Total Length (TL) & $18.87 \pm 1.63(15.4-24.0)$ & 8.63 \\
Standard Length (SL) & $12.68 \pm 0.95(10.0-16.3)$ & 7.52 \\
Pre-dorsal Length-I(PDL1) & $4.20 \pm 0.36(3.0-5.3)$ & 8.61 \\
Pre-dorsal Length-II (PDL2) & $7.32 \pm 0.56(5.9-9.3)$ & 7.59 \\
Pre-anal Length (PAL) & $7.65 \pm 0.57(6.0-10.2)$ & 7.46 \\
Head Length (HL) & $4.14 \pm 0.33(3.1-5.2)$ & 7.97 \\
Body Depth (BD) & $5.98 \pm 0.54(4.8-8.3)$ & 9.10 \\
Snout Length (SnL) & $2.94 \pm 0.30(2.2-3.7)$ & 10.14 \\
Eye Diameter (ED) & $0.84 \pm 0.08(0.6-1.0)$ & 9.43 \\
\hline
\end{tabular}

*Values in parenthesis indicates range $(\mathrm{cm})$

Table 2 : Morphometric traits linked to the total length of Odonus niger landed along Karnataka coast.

\begin{tabular}{lllll}
\hline Morphometric character & Intercept $(\mathbf{a})$ & Regression Coefficient $(\mathbf{b})$ & $\mathbf{Y}=\mathbf{a}+\mathbf{b X}$ & Correlation Coefficient $(\mathbf{r})$ \\
\hline Standard Length (SL) & 1.240 & 0.792 & $\mathrm{Y}=1.240+0.792 \mathrm{X}$ & 0.91 \\
Pre-dorsal Length-I(PDL1) & 0.474 & 0.742 & $\mathrm{Y}=0.474+0.742 \mathrm{X}$ & 0.74 \\
Pre-dorsal Length-II(PDL2) & 0.861 & 0.728 & $\mathrm{Y}=0.861+0.728 \mathrm{X}$ & 0.83 \\
Pre-anal Length (PAL) & 1.001 & 0.692 & $\mathrm{Y}=1.001+0.692 X$ & 0.80 \\
Head Length (HL) & 0.526 & 0.708 & $\mathrm{Y}=0.526+0.708 X$ & 0.72 \\
Body Depth (BD) & 0.508 & 0.839 & $\mathrm{Y}=0.508+0.839 X$ & 0.80 \\
Snout Length (SnL) & 0.249 & 0.840 & $\mathrm{Y}=0.249+0.840 X$ & 0.72 \\
Eye diameter(ED) & 0.342 & 0.304 & $\mathrm{Y}=0.342+0.304 \mathrm{X}$ & 0.28 \\
\hline
\end{tabular}

*Pd"0.01, Y: dependent variable, $\mathrm{X}$ : independent variable

Table 3 : Percentage proportions of morphometric measurements to Total Length (TL) of Odonus nigerlanded along Karnataka coast

\begin{tabular}{ll}
\hline In \% of Total Length (TL) & Mean \pm SD $(\%)$ \\
\hline Standard Length (SL) & $67.32 \pm 2.49(61.00-82.76)$ \\
Pre-dorsal Length-I (PDL1) & $22.28 \pm 1.40(18.63-27.59)$ \\
Pre-dorsal Length-II (PDL2) & $38.87 \pm 1.90(33.62-48.28)$ \\
Pre-anal Length (PAL) & $40.64 \pm 2.13(35.00-50.34)$ \\
Head Length (HL) & $22.05 \pm 1.52(17.46-37.82)$ \\
Body Depth (BD) & $31.75 \pm 1.79(25.00-40.69)$ \\
Snout Length (SL) & $15.60 \pm 1.13(11.82-20.69)$ \\
Eye diameter (ED) & $4.46 \pm 0.50(3.41-6.90)$ \\
\hline
\end{tabular}

*Values in parenthesis indicates range $(\%)$

(2017), but differ from that of Sahayak et al. (2015). The current study recorded 11-18 ventral spines and 12 caudal rays, which were different from 9-23 ventral spines and 10 caudal rays as documented by Sahayak et al. (2015). Slight variations in the merisitic characters may be a result of genetical and/or environmental constituents like salinity, temperature and food availability (Foote et al., 1989).

The LWRs of 358 specimens encompassing 101 females and 257 males were analyzed. The evaluation of LWRs parameters of males, females, and the pooled individuals are delineated in Table 5. The LWRs were highly significant $(p<0.001)$ for males, females, and the pooled individuals with coefficient of determination $\left(r^{2}\right)$ values greater than $0.910,0.913$, and 0.910 , respectively. The calculated allometric coefficient (b) for males, females, and pooled data (Table 5) indicated negative allometric growth (Table 5). The length-weight comparisons derived were W $=0.046 \mathrm{~L}^{2.565}$ and $\mathrm{W}=0.044 \mathrm{~L}^{2.589}$ for male and female, respectively. It was proclaimed exponentially as a linearized equation: $\mathrm{LnW}=$ $3.072+2.565 \mathrm{LnL}\left(r^{2}=0.910\right)$ for males and $\mathrm{LnW}=-3.127+2.589$ $\operatorname{LnL}\left(r^{2}=0.913\right)$ for females. The mean weight of both the sex (adjusted for covariate length) and between the regression slopes (b) of the length-weight relationship did not exhibit any significant difference $(p>0.05)$. Hence, the data of males and females were pooled together and LWRs was represented as $W=0.047 \mathrm{~L}^{2.561}\left(r^{2}\right.$ $=0.910, n=358)$. A t-test conducted separately for males, 
Table 4 : Meristic characters of Odonus nigerlanded along Karnataka coast

\begin{tabular}{lll}
\hline Meristic characters & Mean \pm SD & Coefficient of Variation (\%) \\
\hline Dorsal fin I & $3 \pm 0.00(3)$ & 0.00 \\
Dorsal fin II & $33.95 \pm 1.23(32-36)$ & 3.24 \\
Pectoral fin & $12.60 \pm 1.23(10-14)$ & 9.77 \\
Ventral spines & $15.65 \pm 2.25(11-18)$ & 14.40 \\
Anal fin & $28.65 \pm 1.31(26-30)$ & 4.57 \\
Caudal fin & $11.30 \pm 0.73(10-12)$ & 6.48 \\
Gill rakers & $31.80 \pm 1.20(30-33)$ & 3.76 \\
\hline
\end{tabular}

*Values in parenthesis indicates range

Table 5 : Length-weight relationships (LWRs) of Odonus niger landed along Karnataka coast

\begin{tabular}{|c|c|c|c|c|c|c|c|c|c|c|}
\hline \multirow[t]{2}{*}{ Sex } & \multirow[t]{2}{*}{$\mathbf{N}$} & \multirow{2}{*}{$\begin{array}{l}\text { TL range } \\
\text { (cm) }\end{array}$} & \multirow{2}{*}{$\begin{array}{l}\text { Weight range } \\
\text { (g) }\end{array}$} & \multicolumn{4}{|c|}{ Regression parameters } & & \multirow[t]{2}{*}{$\left|t_{s}\right|$} & \multirow[t]{2}{*}{ Growth type } \\
\hline & & & & a & $95 \% \mathrm{Cl}$ of a & $b$ & $95 \% \mathrm{Cl}$ of b & $r^{2}$ & & \\
\hline Male & 257 & $15.5-24.0$ & $53.29-170.12$ & 0.046 & $0.035-0.062$ & 2.565 & $2.465-2.665$ & 0.910 & 8.586 & $A^{-}$ \\
\hline Female & 101 & $15.4-23.0$ & $52.01-150.59$ & 0.044 & $0.027-0.070$ & 2.589 & $2.429-2.748$ & 0.913 & 5.112 & $A^{-}$ \\
\hline Pooled & 358 & $15.4-24.0$ & $52.01-170.12$ & 0.047 & $0.037-0.060$ & 2.561 & $2.477-2.644$ & 0.910 & 10.313 & $A^{-}$ \\
\hline
\end{tabular}

$N$, sample size; TL, total length; $a$, intercept of relationship; $b$, slope of relationship; $C l$, confidence interval; $r^{2}$,Coefficient of determination; $t_{s, t}$-statistic value; $A^{-}$, negative allometric

Table 6 : Relative condition factor $\left(K_{n}\right)$ of Odonus niger landed along Karnataka coast

\begin{tabular}{|c|c|c|c|c|}
\hline \multirow{2}{*}{$\begin{array}{l}\text { Size group } \\
\text { (cm) }\end{array}$} & \multicolumn{2}{|r|}{ Male } & \multicolumn{2}{|r|}{ Female } \\
\hline & No. of fish & Mean $K_{n} \pm S D$ & No. of fish & Mean $K_{n} \pm S D$ \\
\hline $15-17$ & 19 & $1.0016 \pm 0.0574$ & 12 & $1.0025 \pm 0.0755$ \\
\hline $17-19$ & 87 & $1.0022 \pm 0.0668$ & 46 & $1.0021 \pm 0.0642$ \\
\hline $19-21$ & 113 & $1.0021 \pm 0.0648$ & 34 & $1.0019 \pm 0.0624$ \\
\hline $21-23$ & 36 & $1.0015 \pm 0.0551$ & 08 & $1.0011 \pm 0.0511$ \\
\hline $23-25$ & 02 & $1.0000 \pm 0.0000$ & 01 & - \\
\hline
\end{tabular}

females, and pooled data divulged that the slope of regression line of males, females and pooled data was significantly $(p<0.05)$ different from 3.00 , signifying negative allometric growth $(b<3)$ for the species (Table 5). The calculated $b$ value of LWRs lies within the predicted range of 2.5-3.5 reported for the majority of aquatic animals (Froese, 2006; Assana et al., 2020). The values obtained in this study are comparable with the earlier investigations from the Tuticorin coast (Vaitheeswaran et al., 2015) and the Wadge bank off Kanyakumari (Ramachandran and Philip, 2010). The coefficient value $(b=2.086)$ recorded for the pooled sex from the Gulf of Mannar (Sahayak, 2005) was comparatively lower than that of the present investigation $(b=2.561)$. This indicates that the weight gained by the fish with increase in size was much rapid in this study than in the Gulf of Mannar. The difference in $b$ values in LWRs may be attributed to various factors such as sample size, length range covered, the habitat in which the fish live, fish physiology, ontogenetic development, season, population, sex, gonadal maturity, stomach fullness and health status (Froese et

\section{al., 2011; Rajesh etal., 2020).}

Relative condition factor $\left(K_{n}\right)$ indicates proper growth, feeding intensity, spawning, maturation, and health condition of fish (Nair et al., 1983). In males, the maximum value of $K_{n}$ was documented in October $(1.0023 \pm 0.0686)$ and the minimum in September (1.0008 \pm 0.0413$)$; while in females, the highest and lowest values were in November (1.0046 \pm 0.0590$)$ and August $(1.0001 \pm 0.0180)$ respectively (Fig. 1). Monthly variations in $K_{n}$ of male and female 0 . niger showed similar values around 1 , which indicates almost identical 'condition'. According to Jisr et al. (2018), good growth condition of fish is indicated when $K_{n}$ value was greater than 1 , while $<1$ indicates unhealthy condition. Slightly decreased values recorded for females during postmonsoon months (August-October) indicates diversion of energy for reproduction, and further, little higher $K_{n}$ recorded during November and February could be associated with enhanced feeding intensity to retrieve from the spawning stress 


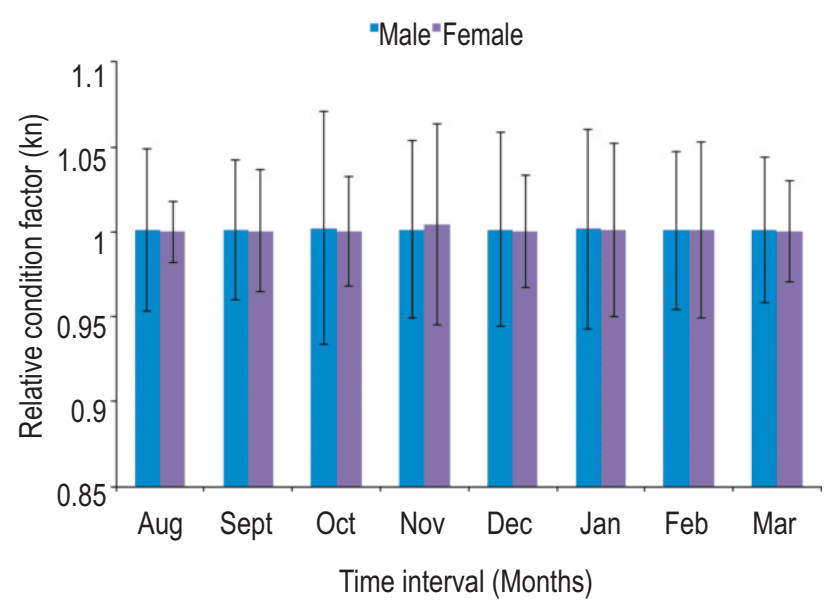

Fig. 1 : Monthly variation in the mean relative condition factor $(K n)$ of male and female Odonus nigerlanded along the Karnataka coast.

(Jisr et al., 2018). Further, the monthly $K_{n}$ of fish is also affected by the seasonal variations of environment, food availability, feeding habits, and swimming behaviour of the fish (Froese, 2006).

The mean $K_{n}$ values of different size groups of both males and females are presented in Table 6 . The $K_{n}$ values of females were lower in the size group of $21-23 \mathrm{~cm}$. Moderate values were noticed in the size groups of $17-19$ and $19-21 \mathrm{~cm}$. The highest $K_{n}$ value was recorded in the size group $15-17 \mathrm{~cm}$. In males, the lowest $K_{n}$ value was noticed in the size group $23-25 \mathrm{~cm}$ and the highest in $17-19 \mathrm{~cm}$ size group. From this investigation, it is obvious that $K_{n}$ values of $O$. niger caught along the Karnataka coast indicated a healthy condition. The $K_{n}$ values of different size groups failed to exhibit any significant difference. The near integrity in $K_{n}$ among the different size groups is attributed to prolonged spawning pattern or to the aspects other than spawning (Zacharia and Jayabalan, 2007). The study may contribute to an invaluable database, which will be helpful in taxonomic and stock assessment studies, which are most important for establishing suitable management measures for Odonus niger landed along the Karnataka coast, South-eastern Arabian Sea.

\section{Acknowledgment}

The authors are thankful to the Dean, College of Fisheries, Karnataka Veterinary, Animal and Fisheries Sciences University, Mangaluru, Karnataka for providing necessary facilities to carry out the research work.

\section{Add-on Information}

Authors' contribution: N.K. Suyani: Collection of samples, analysis and writing draft of the paper; R. Mridula: Experimental design, writing and editing of the paper; K.M. Rajesh: Experimental design, writing and editing of the paper; M.M.
Meshram: Collection of samples and analysis; K. Vandana: Statistical analysis.

Research content: The research content of manuscript is original and has not been published elsewhere.

Ethical approval: NotApplicable

Conflict of interest: The authors declare that there is no conflict of interest.

\section{Data from other sources: NotApplicable}

Consent to publish: All authors agree to publish the paper in Journal of Environmental Biology.

\section{References}

Assana, K., R. Mridula, K.M. Rajesh and T.A. Shaik: Length-weight relationship, feeding traits and nutritional value of mahi mahi (Coryphaena hippurus) in the south eastern Arabian Sea. J. Environ. Biol., 41, 776-781 (2020).

Balasubramanian, T.S., S. Rajapackiam, K.M.S. Ameer Hamsa and H. Mohamad Kasim: On the bumper catch of balistids from Tuticorin with notes on length-weight relationship and gut contents. Mar. Fish. Infor. Sew. T. E. Ser., 137, 18-19 (1995).

Beyer, J.E.: On length-weight relationship, Part 1. Corresponding the mean weight of a given length class. Fish Bytes, 5, 11-13 (1987).

Bookstein, F.L.: Morphometric Tools for Landmark Data: Geometry and Biology. Cambridge University Press, Cambridge London, UK. 465p., (1991).

CMFRI: Marine Fish Landings in India 2019. Technical Report. ICARCentral Marine Fisheries Research Institute, Kochi (2020).

Dwivedi, S.N. and M.R. Menezes: A note on the morphometry and ecology of Brachirus orientalis (Bloch and Schneider) in the estuaries of Goa. Geobios, 1, 80-83 (1974).

Foote, C.J., C.C. Wood and R.E. Withler: Biochemical genetic comparison of sockeye salmon and kokanee, the anadromous and non anadromous forms of Oncorhynchus nerka. Can. J. Fish. Aquat. Sci., 46, 149-158(1989).

Froese, R.: Cube law, condition factor and weight-length relationships: History, meta-analysis and recommendations. J. Appl. Ichthyol., 22, 241-253 (2006).

Froese, R., A.C. Tsikliras and K.I. Stergiou: Editorial note on weight-length relations of fishes. Acta Ichthyol Piscat., 41, 261-263 (2011).

Jisr, N., G. Younes, C. Sukhn and M.H. El-Dakdouki: Length-weight relationships and relative condition factor of fish inhabiting the marine area of the Eastern Mediterranean city, Tripoli-Lebanon. Egypt. J. Aquat. Res., 44, 299-305 (2018).

Johal, M.S., K.K. Tondon and G.S. Sandhu: Mahseer in Lacustrine waters, Gobindsagar reservoir: Morphometry of Tor putitora. In: Mahseer the Game Fish (Ed.: P. Nautiyal). Jagdamba Prakashan Publishers, Dehradun, Rachna, Srinagar, Garhwal pp. 67-85 (1994).

King, M.: Fisheries Biology: Assessment and Management. Fishing News Books Publ., Oxford UK, 341p. (1995).

Laevastu, T.: Manual of methods in fisheries biology. Research on fish stocks. FAO Manuals in Fisheries Science, 4, 1-51 (1965). 
Le Cren, E.D.: The length-weight relationship and seasonal cycle in gonad weight and condition in the perch (Perca fluviatilis). J. Anim. Ecol., 20, 201-219 (1951).

Matsuura, K.: Taxonomy and systematics of tetraodontiform fishes: A review focusing primarily on progress in the period from 1980 to 2014. Ichthyol. Res., 62, 72-113 (2014).

Morey, G., J. Moranta, E. Massuti, A. Grau, M. Linde, F. Riera and B. Morales-Nin: Weight-length relationships of littoral to lower slope fishes from the Western Mediterranean. Fish. Res., 62, 89-96 (2003).

Nair, J.R., N.B. Nair and N.K. Balasubramanian: Condition and relative condition cycles in the tropical glassy perchlet Chanda (=Ambassis) commersonii (Cuv. and Val.) (Pisces: Centropomidae). Proc. Ani. Sci., 92, 415-422 (1983).

Okiyama, M.: An Atlas of the Early Stage Fishes in Japan. Tokai University Press, Tokyo, 1154 p. (1989).

Padmavathi, P., K. Sujatha and V.A. Deepti: Description of trigger fishes (family: Balistidae) and file fishes (family: Monacanthidae) from Visakhapatnam coast of India with an account on first record of Paramonacanthus pusillus (Ruppell, 1828) from India. Ind. J. Fish., 64, 111-122 (2017).

Rajesh, K.M., P. Rohit and S.K. Roul: Length-weight relationships (LWRs) of fourteen marine pelagic fish species in the southeastern Arabian Sea. Thalassas., 36, 371-374 (2020).

Ramachandran, S. and K.P. Philip: Population dynamics of red-toothed triggerfishOdonus niger (Ruppell, 1836) along southwest coast of India. J. Mar. Biol. Assoc. India, 52,105-108 (2010).

Randall, J.E., G.R. Allen and R.C. Steene: Fishes of the Great Barrier Reef and Coral Sea. University of Hawaii Press, Honolulu Hawaii 506 p. (1990).

Sahayak, S.: Length-weight relationship of Sufflamen fraenatus
(Latreille, 1804) and Zenodon niger (Ruppell, 1835). Indian J. Fish., 52, 357-360 (2005).

Sahayak, S., K.K. Joshi and V.S. Murty: Taxonomy of fishes of the family Balistidae in India. In: Summer School on Recent Advances in Marine Biodiversity Conservation and Management, February 16 - March 08, Central Marine Fisheries Research Institute, pp. 219$272(2015)$.

Smith, M.M. and P. C. Heemstra: Family No. 263: Balistidae. In: Smiths' sea fishes (Eds.: M.M Smith and P.C. Heemstra), South Africa, Johannesburg, pp. 876-882 (1986).

Snedecor, G.W. and W.G. Cochran: Statistical Methods. $6^{\text {th }}$ Edn., Oxford and IBH Publishing Co., New Delhi 593 (1967).

Snedecor, G.W. and W.G. Cochran: Statistical Methods. $6^{\text {th }}$ Edn., Oxford and IBH Publishing Co., New Delhi 168-181 (1989).

Usman, B.I., S.M.N. Amin, A. Arshad and M.S. Kamar: Morphometric relations in the grey eel catfish Plotosus canius in the coastal waters of Port Dickson, Peninsular Malaysia. J. Environ. Biol., 37, 573-578 (2016).

Vaitheeswaran, T. and V.K. Venkataramani: Length-weight relationship of Odonus niger (Ruppell, 1836). Tamil. J. Veter. Ani. Sci., 4, 48-51 (2008).

Vaitheeswaran, T., S. Malathi, K. Prabakar, N. Neethiselvan and V.K. Venkataramani: Age and growth of red toothed triggerfish Odonus niger (Ruppell, 1836) (Family: Balistidae) off Thoothukudi, Southeast coast of India $\left(08^{\circ} 53.6^{\prime} \mathrm{N} 78^{\circ} 16^{\prime} \mathrm{E}\right.$ and $08^{\circ} 53.8^{\prime} \mathrm{N} 78^{\circ}$ 32'E) - (36 M). Int. J. Fish. Aquat. Stud., 2, 204-209 (2015).

Vladykov, V.D.: Environmental and taxonomic characters of fishes. Transactions Royal Canadian Institute, 20, 99-140 (1934).

Zacharia, P.U. and N. Jayabalan: Maturation and spawning of the whitefish, Lactarius lactarius (Bloch and Schneider, 1801) (Family Lactariidae) along the Karnataka coast, India. J. Mar. Biol. Assoc. India, 49, 166-176 (2007). 